\title{
The Role of Environmental Heterogeneity in the Seed Rain Pattern
}

\author{
Monique Perini ${ }^{1}$ (D), Henrique Machado Dias² (D), Sustanis Horn Kunz ${ }^{2}$ \\ ${ }^{1}$ Programa de Pós-graduação em Biologia Vegetal, Universidade Federal de Minas Gerais - UFMG, Belo Horizonte/MG, Brasil \\ ${ }^{2}$ Departamento de Ciências Florestais e da Madeira, Universidade Federal do Espírito Santo - UFES, \\ Jerônimo Monteiro/ES, Brasil
}

\begin{abstract}
We focus on understanding the influence of environmental variables on ecological processes, and such a focus promotes an integrated view of forest ecological patterns. The following questions were made: Do variations in temperature, precipitation, litterfall deposition and light intensity influence the density and composition of seed rain in a stretch of the Montane Atlantic Rainforest? Is there a pattern for dispersal syndrome in Montane Atlantic,? Over a period of 12 months, the deposition patterns of seed rains were evaluated. Seed density and species richness correlated with temperature and precipitation, with species richness decreasing with increasing altitude and seed density increasing as a function of the light incidence. Seed rain followed a seasonal deposition pattern with higher seed density and species richness in the higher rainfall period. Increasing trend in seed density was found in mountainous areas with northern and northeastern aspects (higher light incidences).
\end{abstract}

Keywords: dispersal, ecology, light incidence, litterfall. 


\section{INTRODUCTION}

Seed rain is one of the key factors in the dynamics of forests for performing ecosystem maintenance functions (Barbosa et al., 2012). Seed production patterns such as the amount of seeds produced and the period of seed production favour germination and seedling development in situ (Li et al., 2012).

In mountainous rainforests, seed rain contributes to the continuity of the regeneration process, highlighting its importance for conservation and restoration of degraded environments. Understanding seed rain patterns is essential for understanding variations in the composition and structure of plant communities, evaluating successional development, and assisting in the classification of population recruitment parameters (Tabarelli et al., 2012; Toscan et al., 2014).

Seed rain can be considered a bioindicator that contributes to the monitoring of ecosystem dynamics, as it may vary according to environmental factors, such as water availability, temperature, sunlight incidence and wind, fertility, acidity and soil humidity, as well as the presence and abundance of dispersers and predators (Rahbek, 2005). Thus, seed rain varies according to biotic and abiotic interactions in the environment (Barrett, 2013; Zhang et al., 2013).

In mountainous regions, environmental factors often change depending on the altitude (Rahbek, 2005) due to fluctuations in temperature, precipitation, soil humidity, fertility, slope, which are aspects that influence the composition and structure of vegetation and the biological processes of plant communities (Hernández et al., 2012; Joseph et al., 2008).

Studies on variations in species density and richness along altitudinal gradients highlight a decrease in the diversity of species but an increase in species density in high-altitude regions, with species richness peaking at intermediate altitudes (Mccain, 2010; Werenkraut \& Ruggiero, 2011; Qin et al., 2011). In previous studies seeking to analyse seed rain in mountainous environments, there was an influence of altitude in the seed deposition, germination and dispersal patterns, which are fundamental conditions for successional processes and natural regeneration.

In this study, the earlier hypothesis that environmental factors contribute to changes in seed rain patterns in mountainous rainforest was examined. We focus on understanding these patterns because they are the result of the influence of environmental variables on ecological processes, and such a focus promotes an integrated view of forest ecological patterns. The following questions were made: (1) Do variations in temperature, precipitation, litterfall deposition and light incidence influence the density and composition of seed rain in a stretch of the Montane Atlantic Rainforest? We predict that seed density and species richness differ according to environmental factors (Qin et al., 2011). Mountainous areas in the Atlantic Forest biome are not typically susceptible to drought, which is a factor limiting seed production and germination. Thus, we expect seed rain to have the same pattern over periods of both higher and lower rainfall (Morel et al., 2015). (2), Is there a pattern for dispersal syndrome in mountainous forests? We hypothesized that elevation is one of the factors contributing to changes in dispersal syndrome (Mccain, 2010). This study will provide information that supports forest conservation and restoration projects.

\section{MATERIALS AND METHODS}

\subsection{Study area}

The study was conducted in a montane rainforest in "Caparaó" National Park, municipality of Ibitirama, state of Espírito Santo, southeastern Brazil. "Caparaó" National Park is a Federal Conservation Unit located on the border of states of Minas Gerais and Espirito Santo $\left(20^{\circ} 19^{\prime} 20^{\circ} 37^{\prime} \mathrm{S}\right.$ and $\left.41^{\circ} 43^{\prime} 41^{\circ} 53^{\prime} \mathrm{W}\right)$. The climate is subtropical highland (Cwb), with average annual temperature of $16.8^{\circ} \mathrm{C}$ and average rainfall of $1284 \mathrm{~mm}$ (Alvares et al., 2013).

The study area is located in a valley between two mountain escarpments, which have a watercourse between them. There were seven permanent plots (sampling units) with dimensions of $20 \mathrm{~m} \times 50 \mathrm{~m}$ distributed along the valley and parallel to the main watercourse, at altitudes varying between 1112 and 1550 metres, representing variations in vegetation and physical environment. Even-numbered plots were located at the right of the watercourse, and odd-numbered plots were at the left of the watercourse.

\subsection{Seed rain}

For the seed rain study, the tray collection technique for fruits and seeds with fixed collectors was used, one of the most effective methods for collecting propagules 
(Cottrell, 2004). Eight collectors with representation of $50 \%$ of the sample unit were systematically distributed within each plot, totalling 56 collectors in the sampled area. Collectors have structure composed of PVC pipes with $2 \mathrm{~mm}$ nylon mesh screens with dimensions $0.75 \times 0.75 \mathrm{~m}\left(0.56 \mathrm{~m}^{2}\right)$ and height of $0.75 \mathrm{~m}$ from the ground (Clark et al., 2001).

Seed rain collection was conducted monthly from November 2012 to October 2013. The procedure consisted of collecting the material in the field and depositing in plastic bags, which were sent to the laboratory for drying in an oven at $65^{\circ} \mathrm{C}$ for 72 hours. Thereafter, the material was separated into leaves, branches and miscellaneous material. Miscellaneous material was submitted to triage in which viable seeds, which are whole seeds with no apparent physical damage, quantified and identified to achieve the objectives of this study. During triage, seeds were photographed and classified according to morphotype until a more detailed identification could be carried out. For each morphotype, seeds were held in the herbarium in order to support the identification of their taxonomic groups, especially at species level. For identification, seeds were brought to various institutions with seed collections, and a literature search was performed. Whenever necessary, taxonomic specialists were consulted.

\subsection{Statistical analysis}

Despite the 12-month study period, the weather station used for the acquisition of meteorological data had data only from December 2012 onwards; however, due to technical problems at the station, data for October 2013 were also unavailable. Thus, the analyses that required such information were carried out for only ten months of the study period (December 2012 to September 2013).

To examine seed density and species richness, seed rain data of different species were entered into Microsoft Excel, version 2010, for data tabulation, and the PAST 3.04 software was used for data analysis. Spearman correlations was used to assess the relationship between seed rain density and richness and environmental variables such as rainfall and temperature, as well as elevation and the average contribution of litter deposited per sampling unit, and Student's t-test was used to assess the significance of these correlations.
To test the significance in correlations between richness values and absolute density of species per plot, analysis was performed using the Kruskal-Wallis nonparametric test at 5\% significance level. To verify that ecological attributes remained the same between months, the non-parametric Friedman test was conducted $(\mathrm{p}<0.05)$. These statistical analyzes were performed with the Assistat software (version 7.7).

\section{RESULTS}

In the sampled area, we counted 235,296 seeds distributed among 80 morphospecies, of which 40 were identified at species level, 32 at genus level and six at family level (Table 1).

Seed rain species richness was higher in parcel 1. However, this result was significantly different from P5, P6 and P7, according to the Kruskal-Wallis test $(\mathrm{p}<0.05)$ (Figure 1).

Absolute density, defined as the number of individuals of a given species per area unit, in the study area was 138945.6 seeds $/ \mathrm{m}^{2}$. Plots P4 and P7 showed the highest seed density values, only differing significantly from P6, which in turn showed the lowest number of seeds per square metre throughout the valley (Figure 2).

For seed density and species richness, richness peaks were concentrated in the months with the highest rainfall values (November 2012 to March 2013 and October 2013) in plots P1, P2, P3, P4 and P5. In contrast, in plots P6 and P7, the month of measurement had no influence on species richness according to results of the Friedman test $(\mathrm{p}<0.05)$.

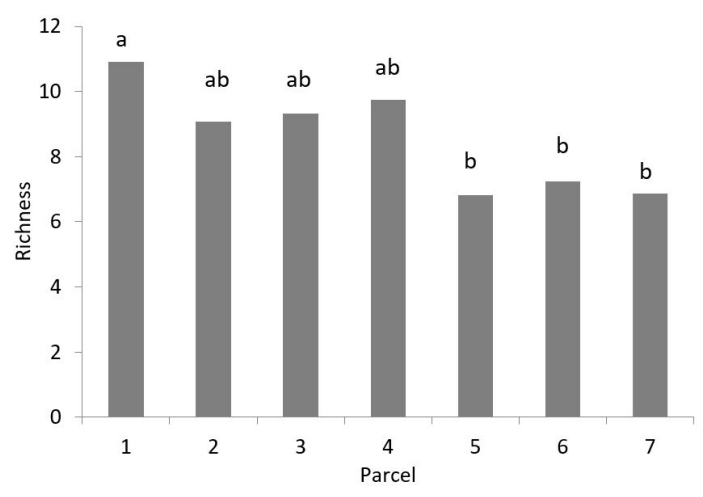

Figure 1. Average species richness per plot in the sampled area. Means labelled with the same letters do not differ, according to the Kruskal-Wallis test at 5\% significance level. 
Table 1. List of species found in seed rain from "Santa Marta" Valley, "Caparaó" National Park, state of Espírito Santo, Brazil.

\begin{tabular}{|c|c|}
\hline Families & Species \\
\hline Annonaceae & Annona sp. 1 \\
\hline Annonaceae & Annona sp. 2 \\
\hline Apocynaceae & Forsteronia cordata (Müll.Arg.) Woodson \\
\hline Apocynaceae & Aspidosperma sp. \\
\hline Asteraceae & Mikania argyreia DC. \\
\hline Asteraceae & Vernonanthura phaeoneura (Toledo) H.Rob. \\
\hline Asteraceae & Vernonia diffusa Less. \\
\hline Asteraceae & Mikania stipulacea Willd \\
\hline Bignoniaceae & Jacaranda puberula Cham. \\
\hline Bignoniaceae & Handroanthus heptaphyllus (Vell.) Mattos \\
\hline Combretaceae & Terminalia mameluco Pickel \\
\hline Euphorbiaceae & Alchornea sp. \\
\hline Euphorbiaceae & Morpho 49 \\
\hline Euphorbiaceae & Alchornea triplinervia (Spreng.) Müll.Arg. \\
\hline Euphorbiaceae & Croton sp. \\
\hline Euphorbiaceae & Pogonophora schomburgkiana Miers ex Benth. \\
\hline Fabaceae & Cassia ferruginea (Schrad.) Schrad. ex DC. \\
\hline Fabaceae & Piptadenia sp. \\
\hline Fabaceae & Machaerium sp. 1 \\
\hline Fabaceae & Leptolobium bijugum (Spreng.) Vogel \\
\hline Fabaceae & Machaerium hirtum (Vell.) Stellfeld \\
\hline Fabaceae & Desmodium sp. \\
\hline Fabaceae & Apuleia leiocarpa (Vogel) J.F.Macbr. \\
\hline Fabaceae & Andira nitida Mart. ex Benth. \\
\hline Fabaceae & Machaerium sp. 2 \\
\hline Fabaceae & Copaifera langsdorffii \\
\hline Fabaceae & Morpho 54 \\
\hline Fabaceae & Machaerium ovalifolium Glaz. ex Rudd \\
\hline Fabaceae & Morpho 77 \\
\hline Fabaceae & Abarema cochliacarpos (Gomes) Barneby \& J.W.Grimes \\
\hline Hypericaceae & Vismia guianensis (Aubl.) Choisy \\
\hline Lauraceae & Ocotea sp. \\
\hline Lauraceae & Morpho 62 \\
\hline Malpighiaceae & Tetrapterys sp. 1 \\
\hline Malpighiaceae & Morpho 8 \\
\hline Malpighiaceae & Byrsonima sericea DC. \\
\hline Malpighiaceae & Tetrapterys sp. 2 \\
\hline Malpighiaceae & Tetrapterys sp. 3 \\
\hline Malpighiaceae & Mascagnia sp. \\
\hline Malpighiaceae & Niedenzuella acutifolia (Cav.) W. R. Anderson \\
\hline Malpighiaceae & Heteropterys sp. 2 \\
\hline Malpighiaceae & Heteropterys sp. 1 \\
\hline Malvaceae & Luehea sp. \\
\hline Melastomataceae & Miconia cinnamomifolia (DC.) Naudin \\
\hline Melastomataceae & Miconia maroana Wurdack \\
\hline Melastomataceae & Miconia sp. \\
\hline Moraceae & Brosimum lactescens (S.Moore) C.C.Berg \\
\hline
\end{tabular}


Table 1. Continued...

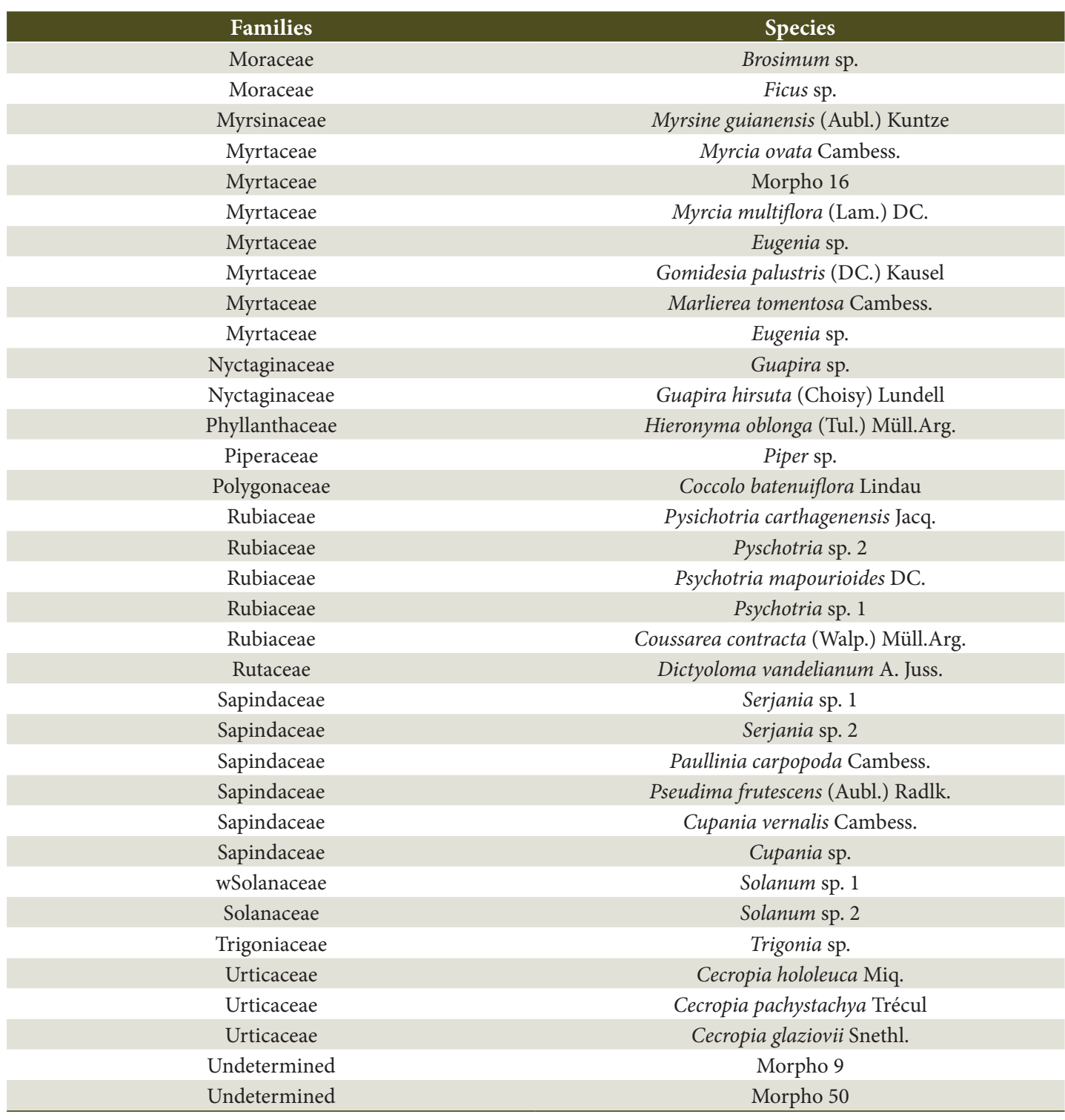

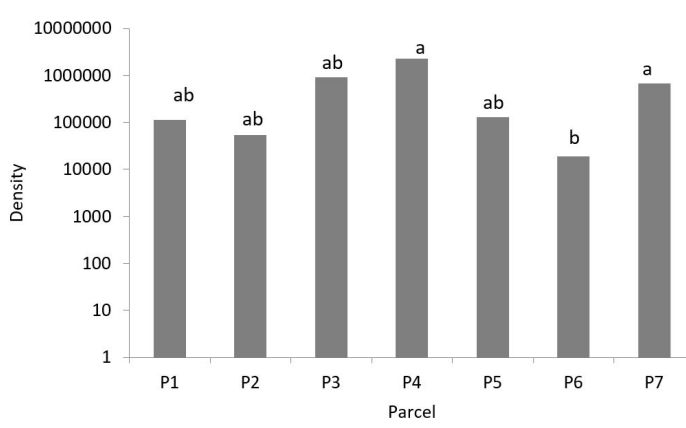

Figure 2. Absolute density of each plot observed in the study period. Means labelled with the same letters do not differ, according to the Kruskal-Wallis test at 5\% significance level.
By associating the monthly absolute density and species richness with the altitude of plots using the Spearman correlation, it was observed that as the altitude increased, species richness reduced. However, the density of certain species increased with increasing altitude. Regarding the average litter deposited per plot, it was observed that although the correlation did not show statistical significance at $1 \%$ or $5 \%$ based on the t-test, the variables followed the same pattern: as the average amount of litter increased, an increase in seed density and richness was observed (Table 2).

The analysis of Spearman correlations of the absolute density of species with environmental variables 
Table 2. Spearman correlations comparing richness and seed rain density with altitude and average litter input per plot in the study area.

\begin{tabular}{|lcc|}
\multicolumn{3}{c}{ Spearman Correlation } \\
\hline & Altitude & Average litter input \\
\hline Density & 0.20 & 0.11 \\
Richness & -0.61 & 0.25 \\
\hline
\end{tabular}

Correlation is significant at 0.05 level.

Table 3. Spearman correlations of absolute seed rain density with precipitation and average temperature of each plot in the study area.

\begin{tabular}{|ccc|}
\hline \multicolumn{3}{c|}{ Spearman Correlation - Absolute Density } \\
\hline & Precipitation & Temperature \\
\hline P1 & 0.44 & $0.66^{*}$ \\
P2 & 0.32 & $0.45^{\star}$ \\
P3 & 0.71 & $0.92^{\star}$ \\
P4 & 0.19 & $0.39^{*}$ \\
P5 & 0.54 & $0.71^{\star}$ \\
P6 & 0.79 & $0.76^{*}$ \\
\hline P7 & -0.16 & $-0.55^{\star}$ \\
\hline
\end{tabular}

${ }^{\star}$ Correlation is significant at 0.05 level.

Table 4. Spearman correlations for species richness of seed rain with both rainfall and average temperature for each plot in the study area.

\begin{tabular}{|ccc|}
\hline \multicolumn{3}{c}{ Spearman Correlation - Species Richness } \\
\hline & Precipitation & Temperature \\
\hline P1 & 0.36 & $0.73^{\star}$ \\
P2 & 0.26 & $0.47^{\star}$ \\
P3 & 0.72 & $0.83^{\star}$ \\
P4 & 0.62 & $0.72^{\star}$ \\
P5 & 0.54 & $0.79^{\star}$ \\
P6 & 0.80 & $0.92^{\star}$ \\
P7 & -0.57 & $-0.37^{\star}$ \\
\hline
\end{tabular}

${ }^{*}$ Correlation is significant at 0.05 level.

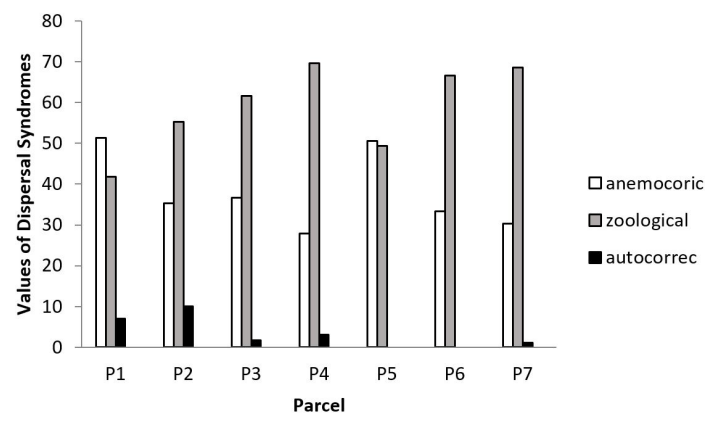

Figure 3. Seed dispersal syndromes within the sampled area. (temperature and precipitation) emphasizes the strong relationship among variables in plots $\mathrm{P} 1, \mathrm{P} 3, \mathrm{P} 5$ and $\mathrm{P} 6$ (Table 3). In P7, there was a negative association for both attributes, suggesting that environmental variables play an inverse role in this plot; i.e., high values of one variable are associated with lower values of the other variable.

Regarding the Spearman correlations among species richness recorded in the seed rain, precipitation and average monthly temperature, plots P1, P3, P5 and P6 show an intense association with analysed variables (Table 4). In P7, the correlation was negative, indicating that in periods of greater precipitation and temperature, seed rain richness tends to be lower.

Species with the highest relative densities were Cecropia glaziovii (49\%), Cecropia hololeuca (18\%), Miconia maroana (17.5\%), Vernonanthura phaeoneura (4\%), Cecropia pachystachya (3.9\%), Mikania stipulacea (2.3\%) and Vernonia difusa (1.5\%).

Regarding seed dispersion, zoochory was a dispersal syndrome that predominated in most plots, where only plots P1 and P5 showed anemochory as the predominant syndrome (Figure 3 ).

\section{DISCUSSION}

There was formation of an environmental gradient in relation to species richness. The highest species richness of this study was reported at low altitude stretches $(1,112 \mathrm{~m})$. Spearman's correlation confirms that, as altitude increases, species richness tends to decrease, suggesting that specific compositions change with environmental gradients. Many studies have demonstrated a pattern in species distribution along altitudinal gradients, with species richness peaking at 1300 metres. McCain (2010) and Wang et al. (2007) demonstrate in their studies that species richness tends to increase at intermediate elevations, followed by a decline as altitude increases (above $2000 \mathrm{~m}$ ).

Species richness is associated with several factors that are influenced by elevation. In this case, climate variables such as temperature and rainfall, in addition to soil conditions, also contribute to this pattern at intermediate altitudes, which further influence the richness of an area due to the specific characteristics of each species and the environmental characteristics that promote their local occurrence (Krömer et al., 2013). 
Zellweger et al. (2015) argue that precipitation and temperature do not directly influence species richness; rather, these variables affect the recruitment of new individuals of different species. Nonetheless, according to the authors, in a temperate forest in Switzerland, species richness was positively correlated only with temperature.

This study, as well as that performed by Zellweger et al. (2015), follows the same pattern, in which only temperature was positively correlated with species richness, with a tendency of increasing richness with increasing temperature in 6 plots (P1 to P6). However, P7 showed the opposite result; although there was no positive correlation between variables, this plot followed a tendency of reducing richness with increasing temperature. This plot (P7) is characterized by the presence of high aluminum, carbon and organic matter content in the soil, in addition to smaller litter contribution, compared with the other plots (Castro, 2014). In this sense, the combination of soil $\mathrm{pH}$, topographic position of plots and availability of light on the forest soil, including open canopies, as discussed by Zhang et al. (2013), contributes to the foundational analysis of species richness.

It should be noted that plots with the greatest plant species richness have lower aluminum content in the soil (Castro, 2014). This compound is considered toxic to plants when found in large amounts in the soil, with some species being more tolerant or intolerant to it. In this case, when exposed to this type of soil (acidic), intolerant species have limited growth (Miguel et al., 2010). Therefore, the lower aluminum content in soils at lower elevations may favour the recruitment of different species in this environment, contributing to the high seed rain richness in P1, P2, P3 and P4.

Species richness and absolute density also fluctuated among months, and months with higher rainfall and temperatures (November 2012 to March 2013 and October 2013) had greater richness and density of individuals in the seed rain.

Rainforests usually have higher reproductive activity from September to March (Morellato et al., 2000). This activity occurs after the dry season, with high accumulation of nutrients in the soil and higher litter production during this period resulting in higher soil nutrient concentrations.
During the study period, the absolute seed rain density was higher from November 2012 to March 2013 and in October 2013 in plots P1 to P6. Only P7 had peak species density in the dry season (March 2013 to July 2013). This fact may be related to environmental variables such as temperature and rainfall.

The relationship between temperature and precipitation and absolute density follows a linear deposition pattern, but only the relationship between absolute density and temperature is statistically significant. Thus, as these variables increase, density also increases; however, in $\mathrm{P} 7$, the correlation was shown to be negative, indicating inverse density values. That is, the higher the precipitation and temperature, the smaller the absolute seed rain density, a fact that may be related to the phenology of species present in this plot.

The phenology of species and the successional stage of the forest may be associated with the mechanism of seed deposition and litter mentioned above. Brun et al. (2001) consider three forests in different successional stages and show that as a forest matures, it tends to have higher litter production during the rainy season.

When relating species richness and density with the mean litter contribution in the "Santa Marta" valley using Spearman correlations, results were not statistically significant. However, this relationship follows a linear tendency: as litter deposition increases, species richness and density also increase.

In tropical rainforests, climatic factors such as sunlight incidence, temperature and rainfall are not limiting to restrict the reproductive phenological development of species, as they are resources available throughout the year. For example, there are no water deficits that would limit seed germination. However, these factors favour the establishment of certain species in the environment (Morel et al., 2015).

Light intensity that affects each environment can influence seed deposition patterns; thus, plots with northern or northeastern aspects (P1, P3, P5 and P7) showed the highest density values in the entire valley. However, there is a slight difference in values between these plots: those with completely northeastern aspect (P3 and P7) had an even higher seed density.

Northern and northeastern aspects contribute to higher seed density due to the higher light incidence on these environments (Oliveira et al., 1995). With higher solar irradiance, temperatures and humidity, 
rainforests have the highest deposition contributions of vegetative and reproductive tissues (Scheer et al., 2009).

Thus, despite having an eastern aspect, plot P4 showed high density value due to the number of individuals in the plot belonging to the genus Cecropia. These species have characteristic inflorescence with a high amount of seeds (Lorenzi, 2009), resulting in even greater value when bunches of these fruits fall in collectors.

With the exception of P4, plots P2 and P6 have eastern, southern, and southeastern aspects, which may result in lower seed concentration in these environments due to the increased dew deposition during the day caused by increased shading, making these areas more humid (Oliveira et al., 1995).

The high density of seeds in environments with higher solar irradiance may be associated with the dynamics of pigments found in fruits in both shaded and sunny environments. Pigments responsible for fruit maturation tend to be excited by different light intensities. In this case, fruits found in areas of high and constant sunlight tend to have an accelerated maturation process, which remains continuous throughout the year (Solovchenko et al., 2006).

This result may explain the higher contribution of seed deposition in the months of higher temperature. It may also help explain the fact that the highest absolute seed densities were found in areas with higher light incidences, as these environmental conditions favour the increased production of fruits and seeds.

Species with the highest relative densities (Cecropia glaziovii, Cecropia hololeuca and Miconia maroana) had characteristically large amounts of seeds produced by their fruits (Lorenzi, 2009). Seeds from species C. glaziovii and $C$. hololeuca were found in all plots. These species have flowers for a long period (August-December), and their fruits mature from November to February, with birds, bats and marsupials acting as their primary dispersers (Lorenzi, 2009). The high occurrence of these species in sample units may be associated with the high efficient zoochoric dispersal system characterized by a variety of seed dispersers, in addition to the high seed production in these species (Rother et al., 2009).

Throughout the "Santa Marta" valley, zoochorous dispersion predominated, as expected in tropical forests (Howe \& Smallwood, 1982). However, plots $\mathrm{P} 1$ and P5 showed anemochory as the main dispersal syndrome. This finding can be understood based on the dynamics of species present in these plots, in which great number of seeds of species from the Asteraceae family were observed.

Asteraceae has long flowering and fruiting periods with high seed production. The fruits of species belonging to this family have pappi and other structures involved in seed dispersion by wind, thus increasing resistance between air and the fruit and extending the time and distance of their dispersal (Maluf \& Wizentier, 1998).

Galetti \& Pizo (1996) and Du et al. (2009) reported that, up to a certain point, elevation is not a limiting factor for zoochorous dispersion because in tropical forests, $90 \%$ of species that produce fleshy fruits are eaten and dispersed by fruit-eating animals, especially mammals and birds. Thus, the phenological pattern of plant species is the key factor that influences the dispersal syndrome and the activity of dispersers.

Plant species tend to enter the reproductive phase at favourable times in order to maximize dispersal success and establishment of new seedlings. The reproductive period is usually initiated by the temperature and humidity of the environment (Morellato et al., 1990). Anemochorous species, which need wind to disperse seeds, show peak seed production in dry periods, unlike zoochorous species, which tend to disperse their seeds at the beginning of the rainy season (Vieira et al., 2012). Galetti et al. (2003) reported that the dynamics of species selecting the optimal time for seed dispersal go beyond the need for favourable environmental conditions: this timing is also important in contributing to the availability of food resources for fauna throughout the year.

Given the importance of understanding seed rain patterns for the establishment and dynamics of forest mountainous ecosystems, data generated by this study may contribute to the development of management and biodiversity conservation programmes in similar regions, supporting programmes and actions aimed at regenerating and restoring degraded areas.

\section{CONCLUSIONS}

Increasing trend in seed density in mountainous areas with northern and northeastern aspects (higher light incidences) and reduction in species richness with increasing altitude were found. However, species density 
and richness follow a deposition pattern that depends on environmental conditions, unlike the dispersal syndrome, which was predominantly characterized by zoochory throughout sampling units.

\section{ACKNOWLEDGEMENTS}

This study was partly financed by the Coordenação de Aperfeiçoamento de Pessoal de Nível Superior - Brasil (CAPES) - Finance Code 001. The authors thank the Conselho Nacional de Desenvolvimento Científico e Tecnológico (CNPq) - Chamada Universal - no. 14/2011, and the Fundação de Amparo à Pesquisa e Inovação do Espírito Santo (FAPES) - Edital Universal - no. 03/2017 for funding this research.

\section{SUBMISSION STATUS}

Received: 29 oct., 2018

Accepted: 4 dec., 2018

\section{CORRESPONDENCE TO}

\section{Henrique Machado Dias}

Departamento de Ciências Florestais e da Madeira, Universidade Federal do Espirito Santo - UFES, Avenida Governador Carlos Lindemberg, 316, Nedtec, CEP 29550-000, Jerônimo Monteiro, ES, Brasil e-mail: henridias@yahoo.com.br

\section{FINANCIAL SUPPORT}

CAPES - Finance Code 001, CNPq Chamada Universal - no. 14/2011, FAPES - Edital Universal - no. 03/2017.

\section{REFERENCES}

Alvares CA, Stape JL, Sentelhas PC, Gonçalves JLM, Sparovek G. Köppen's climate classification map for Brazil. Meteorologische Zeitschrift 2013; 22(6): 711-728. http:// dx.doi.org/10.1127/0941-2948/2013/0507.

Barbosa JM, Eisenlohr PV, Rodrigues MA, Barbosa KC. Ecologia da dispersão de sementes em florestas tropicais. In: Martins SV, editores. Ecologia de florestas tropicais do Brasil. Viçosa: UFV; 2012.

Barrett SCH. The evolution of plant reproductive systems: how often are transitions irreversible? Toronto, Canadá.
Proceedings of the Royal Society 2013; 280(1765): 264-280. http://dx.doi.org/10.1098/rspb.2013.0913. PMid: 23825207.

Brun EJ, Schumacher MV, Vaccaro S, Spathelf P. Relação entre a produção de serapilheira e variáveis meteorológicas em três fases sucessionais de uma Floresta Estacional Decidual no RS. Revista Brasileira de Agrometeorologia 2001; 9(2): 277-285.

Castro KC. Serapilheira e estoque de carbono ao longo de um gradiente altitudinal na Floresta Ombrófila Densa, no Parque Nacional do Caparaó, ES [dissertação]. Jerônimo Monteiro: Universidade Federal do Espirito Santo; 2014.

Clark DA, Brown S, Kicklighter DW, Chambers JQ, Thomlinson JR, Ni J et al. Net primary production in tropical forests: an evaluation and synthesis of existing field data. Ecological Applications 2001; 11(2): 371-384. http://dx.doi.org/10.1890/1051-0761(2001)011[0371:NP PITF]2.0.CO;2.

Cottrell TR. Seed rain traps for forest lands: considerations for trap construction and study design. Journal of Ecosystems and Management 2004; 5(1): 1-6.

Du Y, Mi X, Liu X, Chen L, Ma K. Seed dispersal phenology and dispersal syndromes in a subtropical broad-leaved forest of China. Forest Ecology and Management 2009; 258(7): 1147-1152. http://dx.doi.org/10.1016/j.foreco.2009.06.004.

Galetti M, Alves-Costa CP, Cazetta E. Effects of forest fragmentation, anthropogenic edges and fruit colour on the consumption of ornithochoric fruits. Biological Conservation 2003; 111(2): 269-293. http://dx.doi. org/10.1016/S0006-3207(02)00299-9.

Galetti M, Pizo MA. Fruit eating by birds in a forest fragment insoutheastern Brazil. Ararajuba 1996; 4(2): 71-79.

Hernández L, Dezzeo N, Sanoja E, Salazar L, Castellanos $\mathrm{H}$. Changes in structure and composition of evergreen forests on an altitudinal gradient in the Venezuelan Guayana Shield. Revista de Biología Tropical 2012; 60(1): 11-33. http://dx.doi.org/10.15517/rbt.v60i1.2360. PMid:22458207.

Howe HF, Smallwood J. Ecology of seed dispersal. Annual Review of Ecology and Systematics 1982; 13(1): 201-228. http://dx.doi.org/10.1146/annurev.es.13.110182.001221.

Joseph S, Reddy CS, Pattanaik C, Sudhakar S. Distribution of plant communities along climatic and topographic gradients in Mudumalai Wildlife Sanctuary (southern India). Biological Lett 2008; 45: 29-41.

Krömer T, Acebey A, Kluge J, Kessler M. Effects of altitude and climate in determining elevational plant species richness patterns: a case study from Los Tuxtlas, Mexico. Flora 2013; 208(3): 197-210. http://dx.doi.org/10.1016/j. flora.2013.03.003.

Li B, Hao Z, Bin Y, Zhang J, Wang M. Seed rain dynamics reveals strong dispersal limitation, different reproductive strategies and responses to climate in a temperate forest in northeast China. Journal of Vegetation Science 2012; 23(2): 271-279. http://dx.doi.org/10.1111/j.1654-1103.2011.01344.x. 
Lorenzi H. Árvores brasileiras: manual de identificação e cultivo de plantas arbóreas nativas do Brasil. 2. ed. Nova Odessa: Instituto Plantarum de Estudos da Flora; 2009.

Maluf AM, Wizentier B. Aspectos fenológicos e germinação de sementes de quatro populações de Eupatorium vauthierianum DC. (Asteraceae), São Paulo, SP. Brazilian Journal of Botany 1998; 21(3): 133-145. http://dx.doi. org/10.1590/S0100-84041998000300002.

McCain CM. Global analysis of reptile elevation diversity. Global Ecology and Biogeography 2010; 19(4): 541-553.

Miguel PSB, Gomes FT, Rocha WSD, Carvalho CA, Oliveira AV. Efeitos tóxicos do alumínio no crescimento das plantas: mecanismos de tolerância, sintomas, efeitos fisiológicos, bioquímicos e controles genéticos. CES Revista 2010; 24(1): 12-30.

Morel H, Mangenet T, Beauchêne J, Ruelle J, Nicolini E, Heuret $\mathrm{P}$ et al. Seasonal variations in phenological traits: leaf shedding and cambial activity in Parkia nitida Miq. and Parkia velutina Benoist (Fabaceae) in tropical rainforest. Trees 2015; 29(4): 973-984. http://dx.doi.org/10.1007/ s00468-015-1177-4.

Morellato LPC, Rodrigues RR, Leitão-Filho HF, Joly CA. Estratégias fenológicas de espécies arbóreas em floresta de altitude na serra do Japi, Jundiaí, São Paulo. Revista Brasileira de Biologia 1990; 50: 149-162.

Morellato LPC, Talora DC, Takahasi A, Bencke CC, Romera EC, Zipparro VB. Phenology of atlantic rain forest trees: a comparative study. Biotropica 2000; 32(4b): 811-823. http://dx.doi.org/10.1111/j.1744-7429.2000.tb00620.x.

Oliveira RR, Zaú AS, Lima DF, Silva MBR, Vianna MC, Sodré DO et al. Significado ecológico da orientação de encostas no maciço da Tijuca, Rio de Janeiro. Oecologia Brasiliensis 1995; 1(1): 523-541. http://dx.doi.org/10.4257/ oeco.1995.0101.28.

Qin XW, Li G, Yang GH, Ren XM, Liu ZX, Wang M. Effect of area and geometric constraints on altitudinal patterns of angiosperm plant richness in Mt. Taibai, the Qinling Mountains, China. African Journal of Agricultural Research 2011; 6(25): 5625-5637.

Rahbek C. The role of spatial scale and the perception of large-scale specie-richness patterns. Ecology Letters 2005; 8(2): 224-239. http://dx.doi.org/10.1111/j.14610248.2004.00701.x.

Rother DC, Rodrigues RR, Pizo MA. Effects of bamboo stands on seed rain and seed limitation in a rainforest.
Forest Ecology and Management 2009; 257(3): 885-892. http://dx.doi.org/10.1016/j.foreco.2008.10.022.

Scheer MB, Gatti G, Wisniewski C, Mocochinski AY, Cavassani AT, Lorenzetto A et al. Patterns of litter production in a secondary alluvial Atlantic Rain Forest in southern Brazil. Revista Brasileira de Botanica. Brazilian Journal of Botany 2009; 32(4): 805-817. http://dx.doi.org/10.1590/ S0100-84042009000400018.

Solovchenko AE, Avertcheva OV, Merzlyak MN. Elevated sunlight promotes ripening-associated pigment changes in apple fruit. Postharvest Biology and Technology 2006; 40(2): 183-189. http://dx.doi.org/10.1016/j.postharvbio.2006.01.013.

Tabarelli M, Santo BA, Arroyo-Rodríguez V, Melo FPL. Secondary forests as biodiversity repositories in humanmodified landscapes: insights from the Neotropics. Boletim do Museu Paraense Emílio Goeldi - Ciências Naturais 2012; 7(3): 319-328.

Toscan MAG, Temponi LG, Leimig RA, Fragoso RO. Análise da chuva de sementes de uma área reflorestada do corredor de biodiversidade Santa Maria, Paraná. Ambiência 2014; 10(1): 217-230. http://dx.doi.org/10.5935/ ambiencia.2014.supl.01.

Vieira MF, Fonseca RS, Araújo LM. Floração, polinização e sistemas reprodutivos em florestas tropicais. In: Martins SV, editor. Ecologia de florestas tropicais do Brasil. Viçosa: UFV; 2012

Wang Z, Tang Z, Fang J. Altitudinal patterns of seed plant richness in the Gaoligong Mountains, south-east Tibet, China. Diversity \& Distributions 2007; 13(6): 845-854. http://dx.doi.org/10.1111/j.1472-4642.2007.00335.x.

Werenkraut V, Ruggiero A. Quality of basic data and method to identify shape affectof richness-altitude relationships in meta-analysis. Ecology 2011; 92(1): 253-260. http:// dx.doi.org/10.1890/09-2405.1. PMid:21560695.

Zellweger F, Braunisch V, Morsdorf F, Baltensweiler A, Abegg M, Roth T et al. Disentangling the effects of climate, topography, soil and vegetation on stand-scale species richness in temperate forests. Forest Ecology and Management 2015; 349: 36-44. http://dx.doi.org/10.1016/j. foreco.2015.04.008

Zhang J, Kissling WD, He F. Local forest structure, climate and human disturbance determine regional distribution of boreal bird species richness in Alberta, Canada. Journal of Biogeography 2013; 40(6): 1131-1142. http://dx.doi. org/10.1111/jbi.12063. 